\title{
Impacts of Manures and Manure-Based Composts on Root Lesion Nematodes and Verticillium dahliae in Michigan Potatoes
}

\author{
Emilie Cole, Jian Pu, Henry Chung, and Marisol Quintanilla ${ }^{\dagger}$ \\ Department of Entomology, Michigan State University, East Lansing, MI 48824 \\ Accepted for publication 27 February 2020.
}

\begin{abstract}
The interaction of the root lesion nematode Pratylenchus penetrans and the fungal plant pathogen Verticillium dahliae causes potato early die (PED) complex, which induces premature vine senescence and dramatically reduces yield in potatoes. Management of PED is often achieved through the use of soil fumigants and nematicides, but their adverse effects on soil, human and environmental health, and strict regulations worldwide require alternative control tactics. In this study, we investigated the effects of multiple composts and manures on nematode mortality and PED. In lab assays, root lesion nematodes were exposed to poultry manure, layer ash blend, Dairy Doo, or wood ash for 7 days at rates of $0,0.1,1,10$, and $20 \%$ by volume of product and assessed for nematode survivorship. Additionally, these products were evaluated for volatile fatty acid content to determine if fatty acid content affects
\end{abstract}

ABSTRACT nematode control. In a field trial, the composts and manures were evaluated at two different rates, high (11.2 t/ha) or low (2.8 t/ha), and populations of $P$. penetrans and $V$. dahliae were quantified. Our results show that a $1 \%$ application rate of poultry manure and layer ash blend provided the greatest nematode control in lab assays with 24.5 and $38.2 \%$ reduction, respectively, with greater control at higher rates. In the field, plots treated with poultry manure had significantly higher potato yields and significantly fewer nematodes than control plots. Taken together, our results suggest that poultry manure could be a promising amendment to control PED.

Keywords: disease control and pest management, nematode extraction, nematology, potato early die, poultry manure, Pratylenchus penetrans
Potatoes (Solanum tuberosum L.) are an important commodity in Michigan agriculture, contributing over \$181 million to the state's agricultural value (NASS 2018). However, production is affected by pests and diseases, which increases costs and reduces marketable yields. Disease complexes are difficult to manage due to the interaction between organisms, often from different taxonomic kingdoms. Potato early die (PED) complex, in particular, is caused by the interaction between the root lesion nematode Pratylenchus penetrans (Cobb) (Tylenchida: Pratylenchidae) and the soilborne fungal pathogen Verticillium dahliae (Klebhan) (Glomerellaes: Plectosphearellaceae). Root lesion nematodes feed on roots creating necrotic lesions, while $V$. dahliae penetrates the roots with hyphae, travels to the xylem, and moves throughout the plant. Eventually, $V$. dahliae will clog the vascular tissues and cause wilting (Rowe and Powelson 2002). This synergistic interaction causes damage greater than either pest individually, resulting in reduced nutrient uptake, decreased plant biomass, and premature plant senescence that leads to yield losses up to $50 \%$ (De Ruijter and Haverkort 1999; Rowe and Powelson 2002). With the potential for such substantial yield loss, growers must implement management strategies to control PED.

Cultural control of PED using crop rotation or cover cropping is difficult due to the wide host ranges of both $P$. penetrans and $V$. dahliae (Kimpinski et al. 2000; Larkin et al. 2010; Woolliams 1966). The overwintering microsclerotia of $V$. dahliae adds to the difficulty, as they can persist in the soil for over 10 years (Mace

†Corresponding author: M. Quintanilla; marisol@msu.edu

Funding: Support was provided by the Michigan Potato Industry Commission Project GREEEN (MSUE GR18-096), the National Institute of Food and Agriculture, and AgBioResearch, Michigan State University.

*The $\boldsymbol{e}$-Xtra logo stands for "electronic extra" and indicates that one supplementary figure and one supplementary table are published online.

The author(s) declare no conflict of interest.

(c) 2020 The American Phytopathological Society
1981). Aside from cultural controls, curative chemical control tactics are not yet available for V. dahliae management. Due to these hurdles, many growers have turned to intense preventative chemical control programs that often utilize broad-spectrum soil fumigants or nematicides. Historically, soil fumigants such as methyl bromide, metam sodium, and 1,3-dichloropropene have been popular because of their widespread efficacy in controlling soilborne pests (Collins et al. 2006; Dickson and Hewlett 1988; EPA 2005; Powelson and Carter 1973; Schneider et al. 2008). However, in 2005, the U.S. Environmental Protection Agency (EPA) began to phase out the use of methyl bromide (https://www.epa.gov/odsphaseout/methyl-bromide). Similar fumigant restrictions have been placed across Europe and other countries including Australia, Canada, and Japan (Porter et al. 2010). This has led to the adoption of other forms of control such as alternative chemical fumigation, nematicides, solarization, and biological control (Butler et al. 2012; Giannakou and Karpouzas 2003; Santos et al. 2006). Some countries have also implemented tactics such as soilless media, soil steaming, bio-fumigation, compost, and mulching (FAO 2001). Despite the availability of alternative nonchemical controls, chemical applications remain popular with growers (Oka 2014). These products, however, are still costly to apply and detrimental to soil health thereby highlighting the need for alternative management options to be further explored (Ibekwe 2004; Macalady et al. 1998; O'Malley et al. 2005; South and Carey 2000; South and Gjerstad 1980).

One promising alternative management option is to use compost and manures as potential control agents. Composts and manures are products that have been commonly used in agricultural systems to improve nutrient availability and soil health (Clark et al. 1998; Ghorbani et al. 2008; Stoffella and Kahn 2001). Research has shown that the addition of composts or manures in forms such as liquid swine manure or dairy manure compost can also potentially reduce populations of $P$. penetrans and $V$. dahliae (Conn et al. 2005; Forge et al. 2016; Molina et al. 2014). Some studies have even demonstrated that manure-based composts show pest reduction abilities comparable to biofumigants, compared with other 
feedstocks such as agricultural waste, food waste, or green manures (Korthals et al. 2014; Oka 2010). The mechanism of control in manure-based composts may be attributed to the presence of volatile fatty acids (VFAs) produced by microbial communities during the decomposition process (Brinton 1998). Tenuta et al. (2002) and Mahran et al. (2008) demonstrated that the VFAs present in liquid swine manure, even in small concentrations, have lethal effects on V. dahliae and nematodes. Although these studies showed that the use of manures and composts can reduce PED, the inherent variability of composts both in their feedstocks and micro fauna populations make broad-spectrum recommendations difficult. Therefore, it is important that we examine regionally available products to provide growers with a chemical alternative. We had three objectives in this study. First, we determined whether different commercially available compost and manure products could control or reduce $P$. penetrans populations in a laboratory setting. Secondly, we selected the most effective compost or manure products in the laboratory and determined their success in controlling $P$. penetrans and $V$. dahliae populations in the field. Finally, we examined the VFA content of these different compost or manure products to determine if VFAs are a plausible mechanism for nematode reduction. Results obtained from our study will provide midwestern potato growers with a sustainable nonchemical tactic to control PED without sacrificing yield.

\section{MATERIALS AND METHODS}

Compost bioassays. Nematode culture. Root lesion nematodes ( $P$. penetrans) used in all laboratory experiments were obtained from a laboratory colony from the Department of Plant Pathology at the University of Wisconsin-Madison. Nematodes were reared from a single female specimen collected from Wisconsin field soil, on Gamborg's B-5 media with corn seedlings as the nutrition source. Inoculum was a mixture of male and female, adults, and juveniles.

Compost and manure selection. Two manures (poultry [chicken] manure and worm castings) and four composts (layer ash blend, poultry, Dairy Doo with spelt hulls, and Dairy Doo) were all sourced from Morgan Composting Inc., Sears, MI, U.S.A. (Table 1). Products were evaluated for effects on nematode mortality. Approximately, $40 \mathrm{cc}$ of each product was placed into $50 \mathrm{ml}$ centrifuge tubes (Corning Inc., Corning, NY, U.S.A.) to provide an application rate of $100 \%$, while a $100 \%$ play sand treatment served as the control. Each treatment was replicated five times in a complete randomized block design for lengths of exposure of 1,2,5, or 7 days for a total of 20 arenas per treatment. Replicates were inoculated on day 0 with approximately $200 \mathrm{P}$. penetrans nematodes, immediately irrigated with $5 \mathrm{ml}$ of water, and loosely capped to allow for airflow. After the specified exposure time, the compost or manure was placed onto a modified Baermann pan (Supplementary Fig. S1), consisting of a $100 \times 25 \mathrm{~mm}$ petri dish and a $99 \mathrm{~mm}, 0.64-\mathrm{cm}$ mesh size hardware cloth disk. The hardware cloth disk was lifted off the bottom of the petri dish by folding a $7.0 \times 1.5 \mathrm{~cm}$ piece of hardware cloth at a $45^{\circ}$ angle, placing it in the middle of the dish, and setting the hardware cloth disk on top.
Kleenex facial tissue (Kimberly-Clark Corporation, Neenah, WI, U.S.A.) was then placed on the hardware cloth disk, and the overhanging edges of the tissue were twisted around the inside edge of the petri dish to prevent water from wicking out. The petri dish was filled with enough water to touch the tissue, allowing surviving nematodes to move through the tissue and collect in the water. The compost or manure mixture was then placed onto and spread evenly over the tissue. After $48 \mathrm{~h}$, the liquid in the petri dish was collected to determine the number of surviving nematodes (Supplementary Fig. S1).

Compost rate selection. Two laboratory trials were conducted to determine how different rates of product influenced root lesion nematode mortality. We tested layer ash blend, Dairy Doo, and poultry manure in both trials and a component of the layer ash blend-wood ash in the second trial. In trial 1, products were tested at six rates: $5,15,30,50,75$, and $100 \%$ compost or manure with a $0 \%$ product (100\% sand) control. For trial 2, products were tested at five rates: $0.1,1,5,10$, and $20 \%$ compost or manure, again with a $0 \%$ product ( $100 \%$ sand) control. For both trials, 18 treatments and five replicates were tested in a completely randomized design. Composts were homogenized with play sand on a volumetric basis to achieve the desired rate of compost and obtain a total volume of $20 \mathrm{cc}$. The mixtures were placed into $50 \mathrm{ml}$ centrifuge tubes, irrigated with $5 \mathrm{ml}$ of water, and inoculated with approximately 200 $P$. penetrans nematodes. The caps were placed on top of the tubes but not sealed to allow for airflow. Nematode survivorship was determined after 7 days, using the modified Baermann pan process described previously.

Compost organic acid composition. Dairy Doo, layer ash blend, and poultry manure samples that were 6 months past maturation as well as layer ash blend, poultry manure, and ash samples that were 1 month past maturation were sent to SDK Laboratories (Hutchinson, KS) to determine their concentrations of acetic, butyric, lactic, propionic, and valeric acids. This was completed using the capillary GC method. We considered maturation to be reflective of the point at which Morgan Composting, Inc. determined the product marketable.

Field trial. Experimental design. A field trial was conducted at the Montcalm Research Center (Entrican, MI, U.S.A.; 43.352746, -85.170061 ) in summer 2018. Soil at this site was primarily characterized as a Tekenick-Elmdale loamy sand comprised of approximately $75.1 \%$ sand, $20.9 \%$ silt, and $4.0 \%$ clay with roughly $1.46 \%$ organic matter in the top $30 \mathrm{~cm}$ of soil (U.S. Department of Agriculture-Natural Resources Conservation Service 2019). Previous cropping history in this plot included potato (2015), pearl millet (2016), and corn (2017).

The experiment consisted of a complete randomized block design with eight treatments and four replicates, for a total of 40 plots. Each experimental plot was planted with potato (cultivar Norkotah Russet) seed pieces in $15.25 \times 3.66$ m plots, representing four rows with $86 \mathrm{~cm}$ spacing. All compost (Dairy Doo and layer ash blend) and manure treatments (poultry manure) were applied at a high rate of $11.2 \mathrm{t} / \mathrm{ha}$ and a low rate of $2.8 \mathrm{t} / \mathrm{ha}$. An untreated control was included and Vydate C-LV (oxamyl, 19898, CAS no. 23135-22-0, DuPont de Nemours and Company, Wilmington, DE, U.S.A.),

TABLE 1. Name, description, and nutrient composition of the products used in studies

\begin{tabular}{|c|c|c|c|c|}
\hline Compost/manure & Composition & Nitrogen $\left(\mathrm{TKN}^{\mathrm{a}}\right)(\mathrm{kg} / \mathrm{t})$ & Phosphate $\left(\mathrm{P}_{2} \mathrm{O}_{5}\right)(\mathrm{kg} / \mathrm{t})$ & Potash $\left(\mathrm{K}_{2} \mathrm{O}\right)(\mathrm{kg} / \mathrm{t})$ \\
\hline Layer ash blend & $\begin{array}{l}\text { Composted dairy cow and poultry manure } \\
\text { amended with wood ash }\end{array}$ & 17.7 & 20.3 & 21.1 \\
\hline Poultry manure & Pure poultry manure & 47.1 & 33.9 & 27.7 \\
\hline Dairy Doo w/spelt hulls & $\begin{array}{l}\text { Composted dairy cow manure amended with } \\
\text { spelt hulls }\end{array}$ & 9.3 & 13.3 & 7.4 \\
\hline Worm castings & Castings from red-wriggler worms & 13.3 & 10.5 & 8.8 \\
\hline Poultry compost & Composted poultry manure & 47.1 & 33.9 & 27.7 \\
\hline Dairy Doo & Composted dairy cow manure & 9.6 & 5.3 & 12.5 \\
\hline
\end{tabular}

a Total Kjeldahl nitrogen (TKN) quantifies the total concentration of organic nitrogen, ammonia, and ammonium. 
hereafter referred to as Vydate, was selected as a positive control due to the widespread use in commercial Michigan potatoes. For this study, we did not include a fumigation control due to a lack of residual effects and rapid degradation. With such small plot sizes, there would have been increased risk of contamination in the fumigated fields. Moreover, the goal of this study was to compare composts and manures to the grower standard nonfumigant treatment.

On 4 June 2018, 1 day prior to planting, composts and manures were applied using a top dresser (EcoLawn Applicator, 960 LeonTrepanier, Sherbrooke, Quebec, Canada). The Vydate treatment was applied directly to seed pieces prior to row closure using a $\mathrm{CO}_{2}$ powered backpack sprayer at the label recommended rate for potatoes, 4.7 liter $\mathrm{ha}^{-1}$. Throughout the season, herbicides and insecticides were applied as needed.

Soil and root collection. Soil was collected preplant (4 June), 2 weeks post-plant (22 June), midseason (15 August), and harvest (24 September) by randomly taking 10 soil cores from the center two rows in each plot at a depth of approximately $10 \mathrm{~cm}$. The cores from each plot were homogenized within a plastic bag to equal approximately $1 \mathrm{~kg}$ of soil per plot. After collection, soil was stored in a cooler at $8^{\circ} \mathrm{C}$ until use for analyses. At midseason only, a minimum of $1 \mathrm{~g}$ of root was collected from each plot by uprooting a plant, collecting the fine roots, placing them into a paper bag, and storing at $8^{\circ} \mathrm{C}$ until use.

Nematode extraction and identification. Nematodes were extracted from a $100 \mathrm{cc}$ subsample of soil via the centrifugal flotation method (Jenkins 1964). Within 2 days of collection, roots were washed, dried and weighed to obtain $1 \mathrm{~g}$ of fresh tissue. The roots were then cut into 1 to $2 \mathrm{~cm}$ pieces and placed into $150 \mathrm{ml}$ Erlenmeyer flasks with $50 \mathrm{ml}$ of $1 \%$ bleach solution. The flasks were placed on a wrist-action shaker at $175 \mathrm{rpm}$ for $48 \mathrm{~h}$ (Bird 1971). Since root lesion nematodes can easily pass through a $100-$ mesh sieve, we placed the solution directly into $50 \mathrm{ml}$ centrifuge tubes to ensure accurate counts. All plant-parasitic nematodes were identified to the genus level using morphological characteristics observed using an inverted Nikon TMS microscope between $\times 200$ and $\times 1,000$ magnification. Further identification of nematodes categorized in the genus Pratylenchus was completed using molecular techniques. Extraction of nematode genomic DNA was performed using the quick alkaline lysis protocol previously published by Janssen et al. (2017). Briefly, DNA was extracted from each nematode using a mixture of $10 \mu \mathrm{l}$ of $0.05 \mathrm{~N} \mathrm{NaOH}$ and $1 \mu \mathrm{l}$ of $4.5 \%$ Tween and incubated at $95^{\circ} \mathrm{C}$ for $15 \mathrm{~min}$ before adding $40 \mu \mathrm{l}$ of double-distilled water. One microliter of this extracted DNA was used in a $50 \mu \mathrm{l}$ of PCR reaction using TopTaq DNA polymerase (QIAGEN, Germany) with primers JB3 (5'-TTT TTT GGG CAT CCT GAG GTT TAT$\left.3^{\prime}\right)$ and JB4.5 (5' - TAA AGA AAG AAC ATA ATG AAA ATG-3') using the protocol of Janssen et al. (2017) to amplify the cytochrome c oxidase subunit 1 (COI) gene fragment. Resulting PCR products were cloned into the pGEM-T easy vector systems (Promega) and sequenced using the universal M13F primer at Michigan State University's Research Technology Support Facility. Obtained sequences were searched using NCBI BLAST against other COI sequences in GenBank (https:// www.ncbi.nlm.nih.gov/genbank/) to identify each individual nematode sample down to the species level. Obtained sequences were also submitted to GenBank (GenBank accession numbers MN445189 to MN445198).

Verticillium analysis. Soil collected 2 weeks post-plant and midseason was analyzed for $V$. dahliae microsclerotia germination using the dilution plating method (Nicot and Rouse 1987b). For each sample, $5 \mathrm{~g}$ of soil was mixed with $40 \mathrm{ml}$ of distilled water. We then pipetted a $2.5 \mathrm{ml}$ aliquot, including a large portion of soil particles, onto four plates of Verticillium growth media $(1,000 \mathrm{ml}$ of distilled water, $15 \mathrm{~g}$ of Bacto-agar, $10 \mathrm{ml}$ of 200 proof ethanol, and $0.4 \mathrm{~g}$ of streptomycin sulfate) (Nadakavukaren and Homer 1959). After 2 weeks in a dark environment, the number of $V$. dahliae colony forming units was determined using morphological characteristics (Goud et al. 2003).

At midseason, 10 stems, approximately $12 \mathrm{~cm}$ in length, were collected from each plot directly above the base of the soil. Stems were placed in paper bags and stored in a cooler at $8^{\circ} \mathrm{C}$ prior to

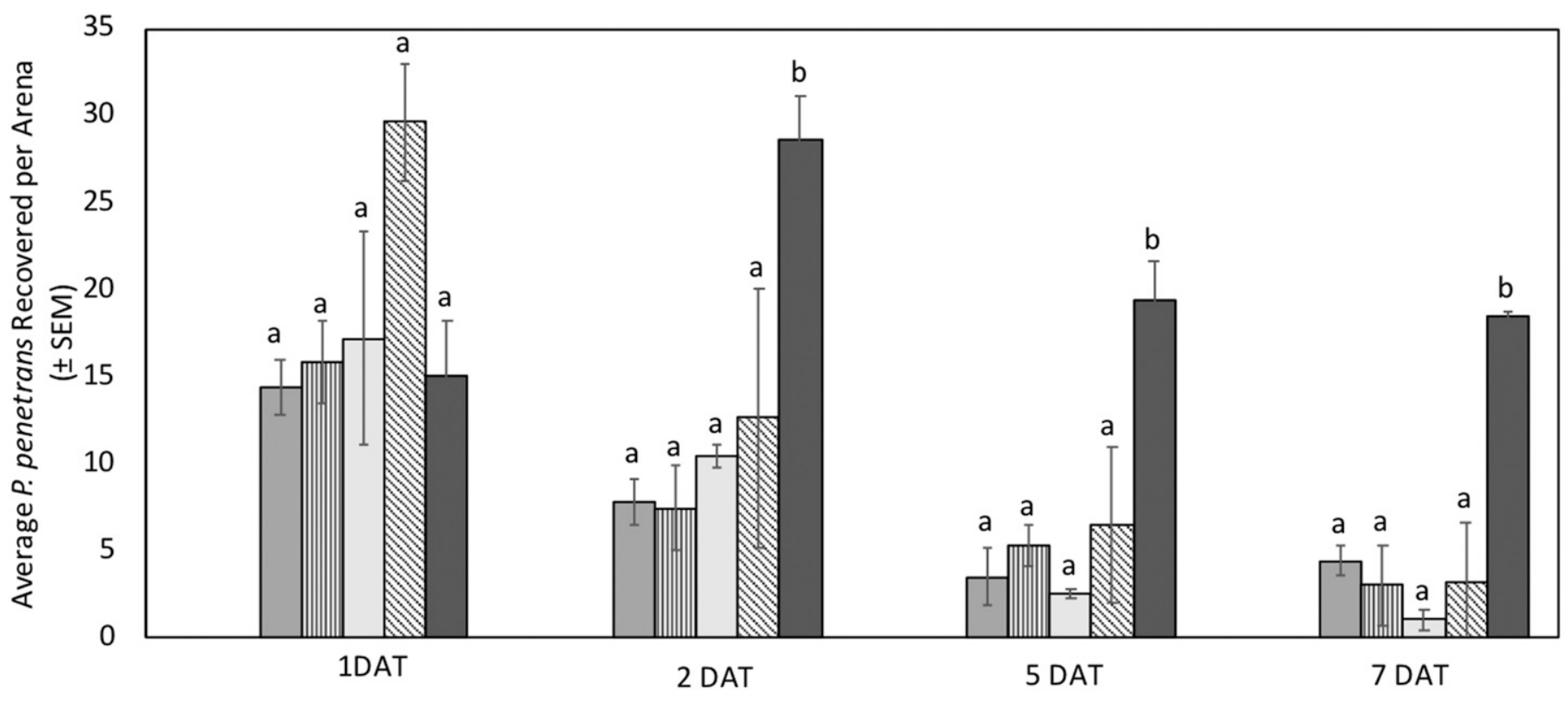

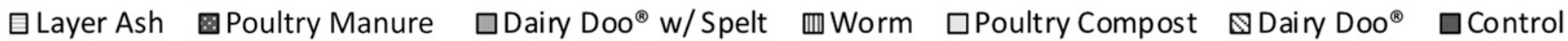

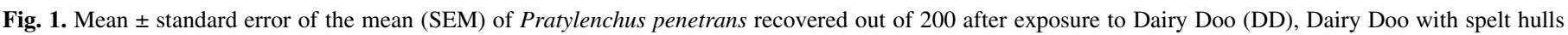

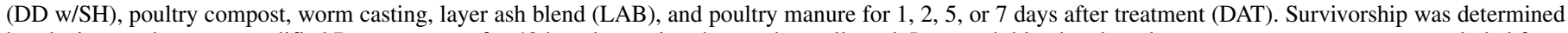

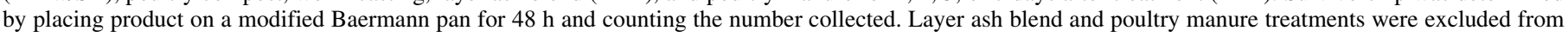

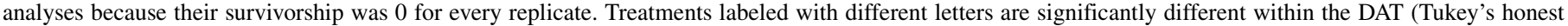
significant difference, $\alpha=0.05, P<0.001)$. 
analysis. Within a week of collection, a $2 \mathrm{~cm}$ slice of each stem was cut, surface sterilized with a $5 \%$ bleach solution, and placed vertically on Verticillium growth media (Nicot and Rouse 1987a). A total of five stems were placed on each plate in a circular arrangement. The plates were kept in a completely dark environment at room temperature for 2 weeks, after which the number of stems with $V$. dahliae germination was counted.

Yield. On 24 September, a 7-m row was harvested from each plot using a potato harvester. The potatoes were then washed, weighed, and graded. The total yield and size distribution was determined. Size classifications were as follows: oversize, $\geq 8.3 \mathrm{~cm}$; grade A, $4.8 \geq 8.3 \mathrm{~cm}$; and grade $\mathrm{B},<4.8 \mathrm{~cm}$. Tubers with shape defects were culled and labeled as pickouts.

Statistical analysis. All statistical analyses were performed using R version 3.5.1 (R Core Team 2018). Nematode counts from the lab trials and the field trial as well as $V$. dahliae soil populations
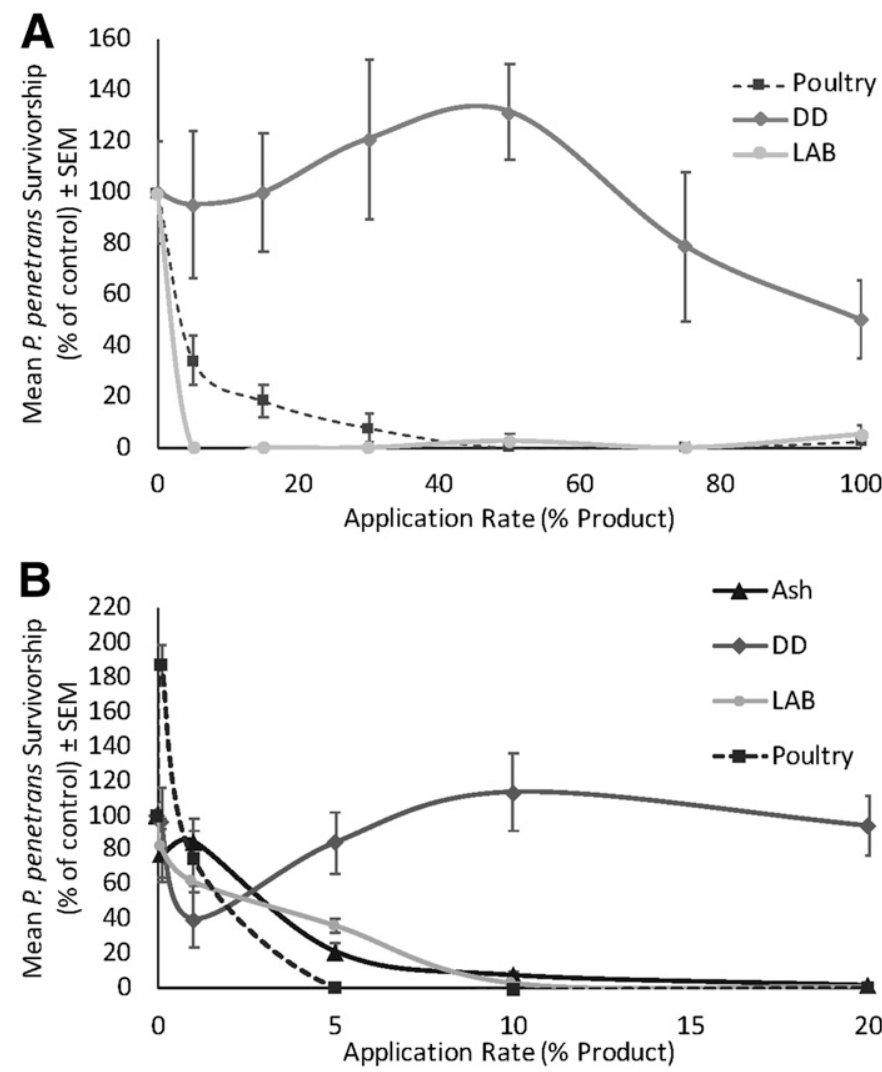

Fig. 2. Mean \pm standard error of the mean (SEM) of Pratylenchus penetrans survivorship as percent control after 7-day exposure to A, poultry manure (Poultry), Dairy Doo (DD), or layer ash blend (LAB) at rates of 0, 5, 15, 30, 50,75 and $100 \%$ compost and exposure to $\mathbf{B}$, ash, Dairy Doo (DD), layer ash blend (LAB), and poultry manure (Poultry) at rates of $0,0.1,1,5,10$, and $20 \%$ product. Survivorship was determined by placing product on a modified Baermann pan for $48 \mathrm{~h}$ and counting the number collected. Survivorship over $100 \%$ indicates greater survivorship than the control. were analyzed using a generalized linear model with a negative binomial distribution. In the compost and manure selection and rate selection trials, many treatments recovered a mean of 0.0 nematodes and were therefore excluded from the model due to inability to predict with zeros. Verticillium stem presence was analyzed using a generalized linear model with a binomial distribution. Means separation was completed using Tukey's honest significant difference (HSD) with the "emmeans" package (Lenth et al. 2019). Significant differences in yield between treatments were determined by using a generalized linear model with a normal distribution followed by Tukey's HSD post hoc test $(\alpha=0.05)$.

\section{RESULTS}

Low concentrations of layer ash blend, poultry manure, and Dairy Doo significantly reduce $P$. penetrans survivorship in a laboratory trial. To determine the effects of different composts and manures on PED, we first performed laboratory trials, focusing on the survivorship of $P$. penetrans exposed to four compost and manure products at various exposure times. Our results show that treatment and duration of exposure significantly influenced $P$. penetrans survivorship and there was a significant interaction between the two effects $\left(\chi^{2}{ }_{12,140}=0.92, P<0.001\right)$ (Fig. $1)$. Over the course of $1,2,5$, or 7 days, zero $P$. penetrans were recovered for each replicate treated with either layer ash blend or poultry manure, suggesting that these two treatments can significantly reduce survivorship of $P$. penetrans nematodes rapidly. Dairy Doo, Dairy Doo with spelt, worm castings, and poultry compost did not result in any significant differences in nematode survivorship compared with the control treatment at 1 day after treatment. A significant reduction in nematode survivorship was observed however at 2, 5, and 7 days after treatment in the Dairy Doo, Dairy Doo with spelt, worm castings, and poultry compost treatment compared with the controls (Fig. 1). Since Dairy Doo is the most popular product currently used among growers, we opted to further test its nematocidal properties.

As all treatments showed significant reduction of $P$. penetrans survivorship after 2 days, we wondered if lower concentrations of these treatments can similarly influence $P$. penetrans survivorship in the course of 7 days. We repeated the same experiments using 0 , $15,30,50,75$, or $100 \%$ of three treatments (Dairy Doo, layer ash blend, and poultry manure) and measured nematode survivorship after 7 days of exposure. Nematode survivorship varied significantly among the different application rates $\left(\chi^{2}{ }_{6,90}=22.5, P<\right.$ $0.001)$. Dairy Doo treatments resulted in greater mean ( \pm standard error of the mean [SEM]) survivorship (\% of control) for the $15 \%$ $(100 \pm 23.0 \%), 30 \%(121 \pm 21.2 \%)$, and $75 \%(131 \pm 18.6 \%)$ compost treatments (Fig. 2A). Only at $100 \%$ Dairy Doo did survivorship dramatically decrease with a $50 \%$ decline compared with the control. Poultry manure steadily decreased survivorship with increasing rate, ultimately reaching $0 \%$ with 50 and $75 \%$ manure treatments. Layer ash blend treatments significantly reduced nematode survivorship to $0 \%$ with just a $5 \%$ application rate. Survivorship remained less than $5 \%$ for all rates of the layer ash blend treatment (Fig. 2A).

TABLE 2. Volatile fatty acid concentration in 1 month and 6 months past maturity compost and manure samples

\begin{tabular}{|c|c|c|c|c|c|}
\hline \multirow[b]{2}{*}{ Sample } & \multicolumn{5}{|c|}{ Volatile fatty acid } \\
\hline & Lactic $(\%)$ & Acetic $(\%)$ & Butyric (\%) & Propionic (\%) & Valeric (ppm) \\
\hline Layer ash (1 month $)^{\mathrm{a}}$ & $<0.01$ & 0.68 & 0.17 & 0.02 & $<0.01$ \\
\hline Layer ash (6 months) & $<0.01$ & 0.02 & $<0.01$ & $<0.01$ & $<0.01$ \\
\hline Poultry manure (1 month) & $<0.01$ & 0.10 & 0.02 & 0.01 & 0.01 \\
\hline Poultry manure (6 months) & $<0.01$ & $<0.01$ & $<0.01$ & $<0.01$ & $<0.01$ \\
\hline Dairy Doo (6 months) & $<0.01$ & $<0.01$ & $<0.01$ & $<0.01$ & $<0.01$ \\
\hline Wood ash (1 month) & $<0.01$ & $<0.01$ & 0.05 & $<0.01$ & $<0.01$ \\
\hline
\end{tabular}

a Samples followed by 1 month or 6 months indicates that the product is 1 month or 6 months past maturity for composts or collection for other products. 
The significant reductions in nematode survivorship at lower rates of application in the layer ash blend and poultry manure treatment prompted us to further evaluate even lower rates that would be practical for field application. We repeated the same experiment using $0,0.1,1,5,10$, and $20 \%$ application rates of the same three treatments of Dairy Doo, poultry manure, and layer ash blend. In addition, because the layer ash blend treatment was so effective in our trials, we also included a component of layer ash blend, wood ash, in this set of experiments. $P$. penetrans nematodes were again exposed to these treatments for 7 days. Our results showed that type and rate of amendment significantly influenced the survivorship of nematodes and there was a significant interaction between treatment and rate $\left(\chi^{2}{ }_{5,100}=\right.$ $20.5, P<0.001)$. At the lowest rate of $0.1 \%$ product, all products performed similarly with a slight decline in survivorship (Fig. 2B). Nematode survivorship (\% of control) was significantly greater in poultry manure treatments with a mean $( \pm$ SEM $)$ of $187.25 \pm 11.53 \%$ compared with $96.07 \pm 20.59 \%$ in Dairy Doo $(P=0.008), 81.37 \pm 17.16 \%$ in layer ash blend $(P<0.001)$, and $77.45 \pm 15.29 \%$ in ash $(P<0.001)$ at the $0.1 \%$ rate $($ Fig. $2 \mathrm{~B})$. Increasing the rate of poultry manure from 0.1 to $1.0 \%$ reduced mean survivorship by more than half, while increasing the rate to $5 \%$ decreased survivorship to only $0.98 \pm 0.98 \%$. Low survivorship continued for 10 and $20 \%$ poultry manure treatments as well, with $0.0 \pm 0.0 \%$ and $0.98 \pm 0.98 \%$ mean survivorship, respectively. The layer ash blend consistently decreased nematode survivorship with increasing application rate as well. Incorporating 5\% layer ash blend decreased the mean survivorship to $36.27 \pm 3.98 \%$ compared with the control, while $10 \%$ layer ash blend reduced survivorship nearly entirely to $2.94 \pm$ $1.96 \%$. Rates of $5 \%(P=0.001), 10 \%(P<0.001)$, and $20 \%(P<$ $0.001)$ layer ash blend were significantly different from no treatment. Ash alone performed similar to the layer ash blend with rates greater than $1 \%$ showing a significant reduction in $P$. penetrans nematode survivorship $(P<0.001)$. Low survivorship when exposed to low rates suggests that the products could be beneficial for in-field nematode control.

VFA composition varies between one-month and sixmonth compost and manure samples. Previous studies have suggested that VFA in manure may have nematocidal properties and affect nematode mortality (Mahran et al. 2008). To determine if there is a functional link between $P$. penetrans mortality and the VFA content of our treatments, we evaluated the composition of our different compost and manure treatments. As VFAs are short lived within composts or manures (Brinton 1998; Plachá et al. 2013), we also wanted to determine differences in VFA composition and concentration between manures and composts 1 month and 6 months past maturity. Data showed that concentrations of VFAs were not detectable in Dairy Doo samples or the poultry manure 6 months past maturity. The greatest concentrations of VFAs were

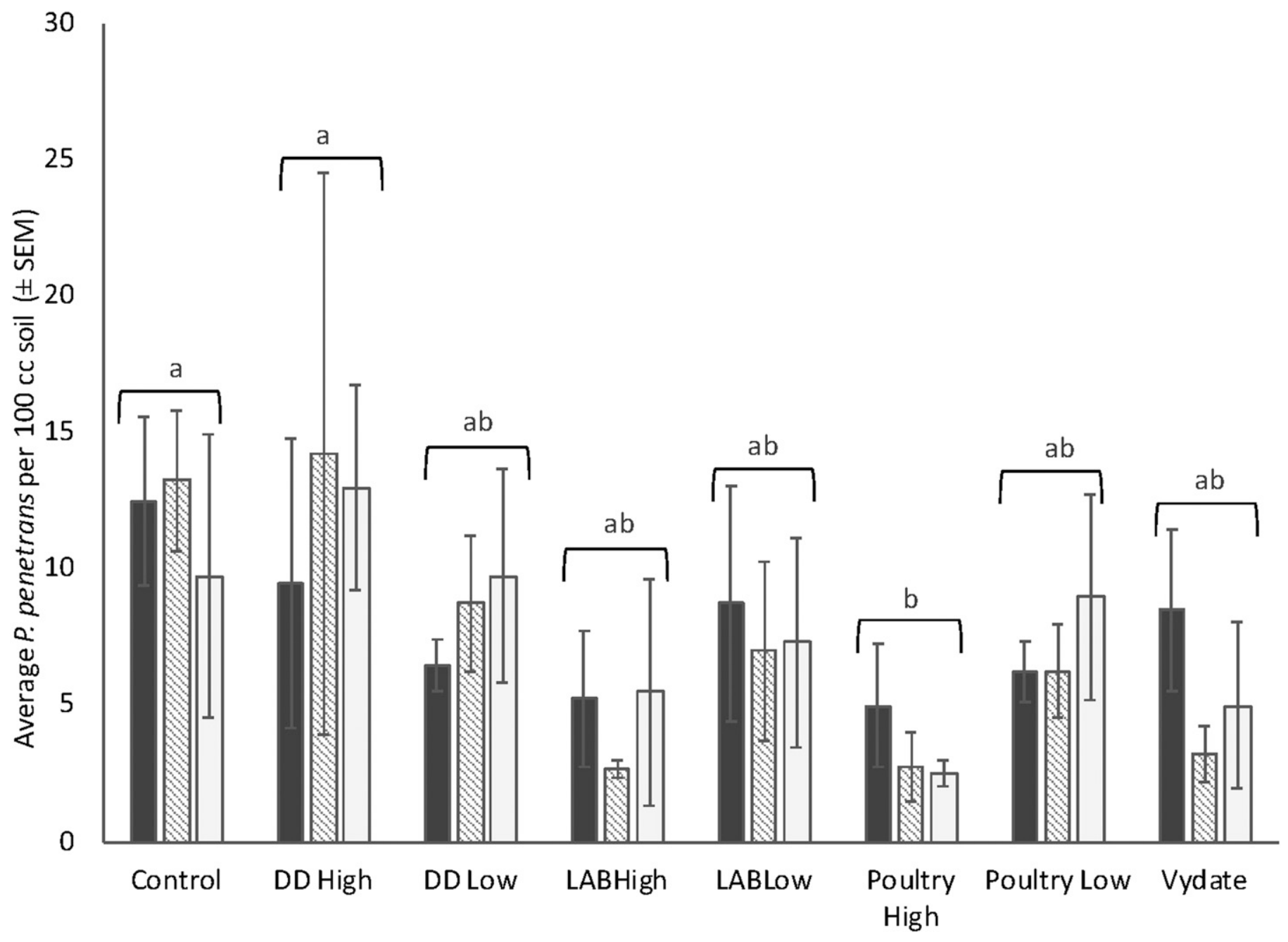

Initial $\quad$ 2wk post plant $\square$ Harvest

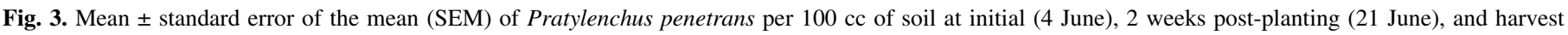

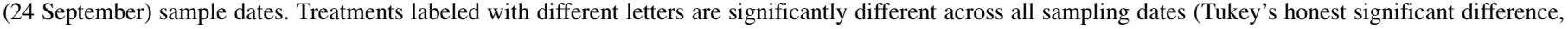
$\alpha=0.05, P=0.009$ ). 
found in the layer ash blends, poultry manure 1 month past maturity, and the wood ash. Butyric and acetic acids were found in the highest concentrations suggesting these compounds could be a factor for the observed reductions in nematode survivorship. Lactic and valeric acids were found in low concentrations only in the poultry manure 1 month past maturity (Table 2). This suggests that the age of the manure or compost should be taken into consideration when using to control nematodes.

Field trial of different manures and composts showed that poultry manure can significantly reduce $P$. penetrans populations. Our laboratory experiments suggest that layer ash blend, poultry manure, and Dairy Doo significantly reduce
$P$. penetrans survivorship. To assess their efficacy in the field, we conducted a field trial in the summer 2018 to assess the effects of these manures and composts on P. penetrans populations in the soil as well as potato yields.

To determine the efficacy of the treatments on reducing nematode populations, soil samples were collected throughout the season. Morphological identification indicated that the field collected root lesion nematodes belonged to the genus Pratylenchus. Seven out of 10 samples showed $100 \%$ identity to the COI sequences of $P$. penetrans. The highest BLAST hit of the next two samples showed 93.38 and $92.35 \%$ hit to $P$. penetrans COI sequences, respectively, suggesting that either there is diversity within these

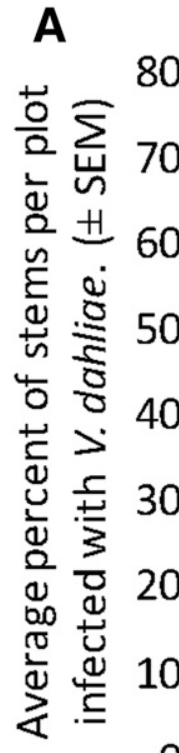

70 
$P$. penetrans individuals or that these individuals belong to an unidentified subspecies closely related to $P$. penetrans. The highest BLAST hit of the last sample showed $92.35 \%$ identity to another nematode species, Pellioditis marina. Taken together, our results suggest that most of the nematodes in this study are identified as P. penetrans (Supplementary Table S1).

Midseason samples showed low populations of root lesion nematodes with an average of $3.0 \pm 0.4 P$. penetrans per $100 \mathrm{cc}$ of soil per plot. Because of this, the midseason date was excluded from analyses to prevent extraneous results. For the remaining samples taken preplant (initial), 2 weeks post-plant and at harvest, $P$. penetrans populations varied significantly among treatments $\left(\chi^{2} 6,120=17.07, P=0.009\right)$, but they were not significantly different across sampling dates $(P=0.86)$ (Fig. 3). Over the course of the entire season, only the plots treated with a high rate $(11.2 \mathrm{t} / \mathrm{ha})$ of poultry manure had significantly fewer $P$. penetrans per $100 \mathrm{cc}$ of soil compared with the control $(P=0.0078)$. The other treatments, including the Vydate treatment, did not significantly reduce the $P$. penetrans in our trial (Fig. 3). Taken together, our field trial results suggest that the application of poultry manure can be an effective method at reducing and controlling $P$. penetrans populations in the field.

Field trial of different manures and composts did not affect Verticillium infection rate. To assess whether manure and compost treatments can also reduce the number of potato plants affected with $V$. dahliae, we collected stems and soil throughout the season to determine their $V$. dahliae infection rate. The majority of stems regardless of treatment were infected and we did not observe significant differences in infection between treatments $(P=0.75$, Fig. 4A). In soil collected 2 weeks post-planting and midseason, the number of $V$. dahliae germinated propagules varied significantly among sampling date $\left(\chi_{6,64}^{2}=20.8, P=0.002\right)$ and were only significantly different among treatments in soil sampled 2 weeks after planting. At 2 weeks post-treatment, plots treated with layer ash blend at a low rate (LAB Low) had an average $( \pm$ SEM) of $5.25 \pm$ 2.0 germinated $V$. dahliae colonies per $10 \mathrm{~g}$ of soil per plot (Fig. 4B). None of the treatments, including the use of Vydate, are significantly different from the controls with regards to V. dahliae infection. These results suggest that manures and composts tested in this study are not effective for control of $V$. dahliae infection of potato plants in the field.

Field trial of different manures and composts resulted in greater yields in poultry manure-treated plots. At the end of the season, we collected yield from a 7-m row in each plot to determine treatment effects on marketable (grade A and B) and unmarketable (pickout and oversize) yields. Grade A tuber yield varied significantly between treatments $\left(\chi_{6,32}=39.8, P=0.005\right)$, and the poultry manure low treatment had significantly more grade A tubers compared with the control $(P=0.038)$ with a mean $( \pm$ SEM) of $12.25 \pm 1.8$ and $5.76 \pm 0.7 \mathrm{~kg}$ harvested, respectively (Fig. 5A). None of the treatments had a significant impact on grade B $(P=0.568)$, oversize $(P=0.838)$, or pickout $(P=0.255)$ yields (Fig. 5B to D). Overall, the greatest yields were observed in poultry manure high treatment, suggesting the addition of poultry manure could reduce yield and revenue losses.

\section{DISCUSSION}

In lab assays, nematode survivorship significantly decreased with increasing application rate for the layer ash blend and wood ash treatments as well as poultry manure at rates greater than $0.1 \%$. In these treatments, butyric acid was detectable only in samples collected 1 month past maturity with the highest concentrations in the layer ash blend $(0.17 \%)$ followed by wood ash $(0.05 \%)$ and poultry manure $(0.02 \%)$. Butyric acid has nematocidal properties and can reduce plant parasitic nematode survivorship by more than 94\% (Browning et al. 2004; Mahran et al. 2008). In the layer ash blend, butyric acid concentrations were $1.7 \mathrm{mg} \mathrm{g}^{-1}$ in the bioassay, providing a plausible mechanism for nematode mortality. Moreover, the 1-month-old layer ash blend had a concentration of $0.68 \%$ acetic acid, which also had lethal effects on $P$. penetrans when extracted from liquid hog manure (Mahran et al. 2008). It is important to note that the concentrations of potentially lethal VFAs within the tested products depended on the age of the material;
Grade A

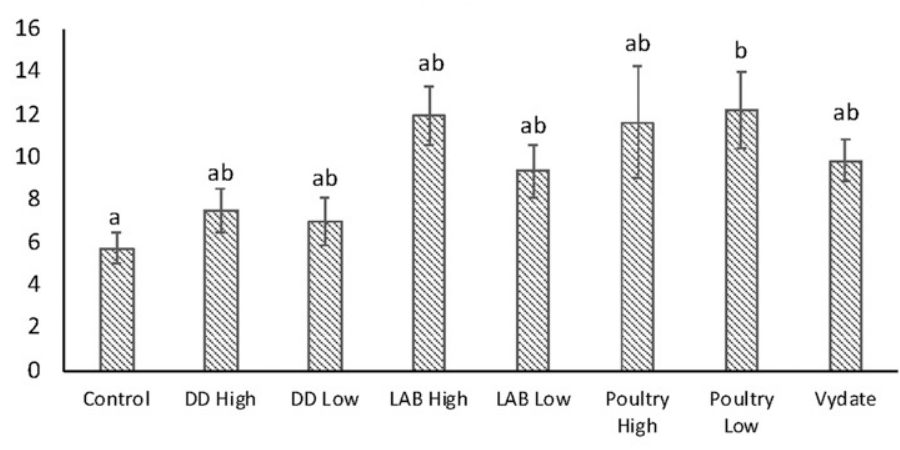

Oversize

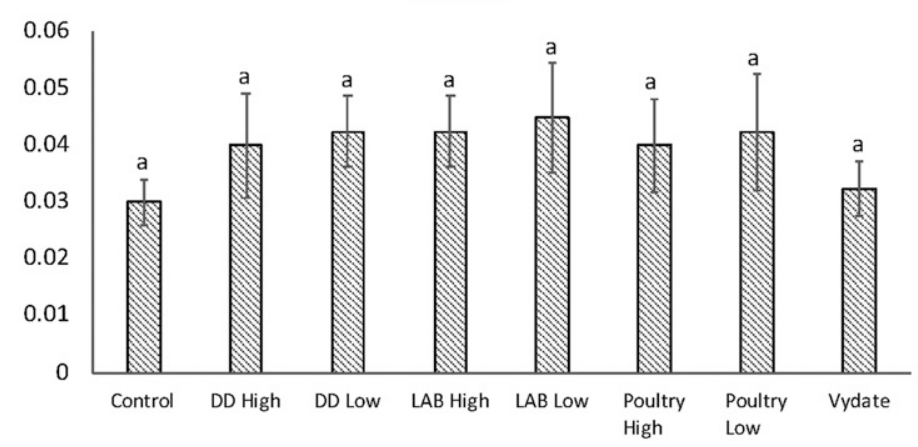

Grade B

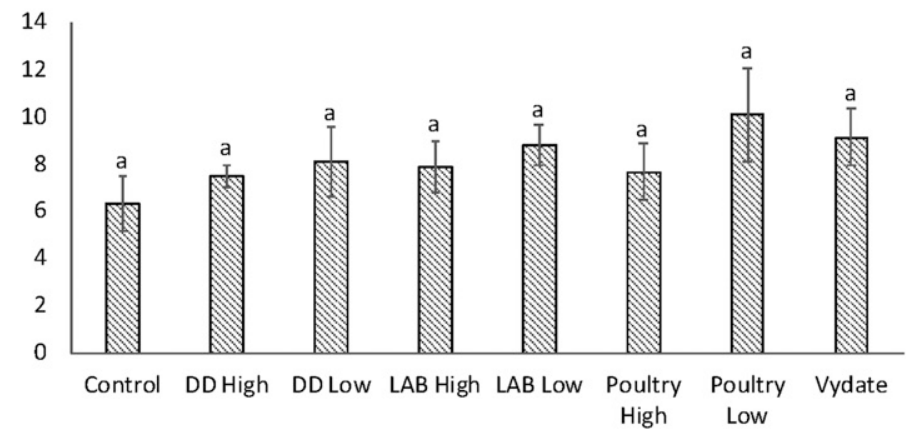

Pickouts

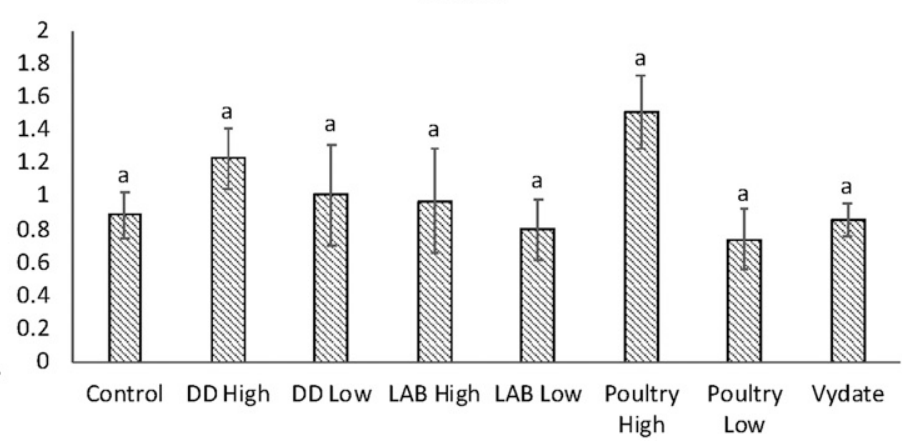

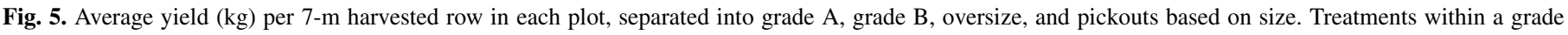
class labeled with different letters are significantly different (Tukey's honest significant difference, $\alpha=0.05, P=0.03$ ). 
therefore, providing consistent nematode control over time could be problematic (Brinton 1998). Most VFAs are not long-lived within composts or manures and are either broken down rapidly by microorganisms, degraded, or absorbed, thus reducing the longevity of their antagonistic properties (Brinton 1998; McBride et al. 2000).

Surprisingly, wood ash may also play a critical role in reducing nematode populations since it performed similarly to the layer ash blend in reducing nematode survivorship. The mechanism behind wood ash's effects on plant parasitic nematodes, however, is still relatively unclear. Wood ash is characteristically nutrient dense with a high $\mathrm{pH}$ and adsorption potential; however, these factors are not directly implicated in reduced root lesion nematode populations (Demeyer et al. 2001; Vestergård et al. 2018), but they may directly increase antagonistic microbial populations (Mkhabela and Warman 2005; Nagy et al. 2004). It is plausible that the increase in antagonistic microbes could reduce root lesion nematode populations, but the rapid decline in nematode survivorship observed in the lab assays suggests the mechanism is likely more direct. Alternatively, the ash may trigger the saponification of the lipid-dense epicuticle of the nematodes increasing their susceptibility to desiccation (Davies and Curtis 2011; Mkhabela and Warman 2005), but further studies such as examining the effect of a wood ash solution on nematode cuticle as well as its effect in the field are needed to fully understand the mechanism.

In the field, we determined that the root lesion species present were predominantly $P$. penetrans. At time of preplanting, composts and manures were less than 1 month past maturity at rates of 0.125 and $0.5 \%$ compost per acre furrow slice for low and high rates, respectively. Despite having the highest VFA concentration and best nematode control in the lab assays, layer ash blend treatments did not have a significant effect on nematode populations. Although populations declined 2 weeks after treatment for the layer ash blend high and poultry low treatments, mean abundance reached or exceeded initial abundance by harvest. This may indicate that the nematocidal properties of the composts and manures dissipated over the course of the season allowing populations to recover through natural reproductive cycles. On the other hand, the poultry high treatment did result in significantly fewer nematode populations compared with the control over the course of the season. Similar to our findings in the field, poultry manure caused significant declines in $P$. penetrans populations in different cropping systems over the course of one or more growing seasons (Conn and Lazarovits 1999; Everts et al. 2006; Forge et al. 2016). Although we hypothesize that VFA composition in the tested products contributed to the decline in nematode survivorship, other mechanisms may be responsible such as ammonia concentrations, antagonistic biological organisms, or a combination thereof (Oka 2010).

In the field, $V$. dahliae microsclerotia germination did not significantly differ between treatments and the control. All treatments except for the layer ash blend experienced mean decreases in $V$. dahliae germination in soil collected at midseason. Alternatively, in the low layer ash blend we observed the lowest amount of microsclerotia germination in potato stems collected at midseason. VFAs have also been implicated in reduced $V$. dahliae germination in fields treated with liquid swine manure (Conn et al. 2005). Acetic acid in particular has inhibitory effects on germination when microsclerotia are exposed for longer periods of time (Tenuta et al. 2002).

Interestingly, $V$. dahliae germination from soil was greater in plots treated with high rates of layer ash blend and poultry manure compared with their low rate counterparts.

Additionally, the abundance of germinated microsclerotia increased over the course of the season for the layer ash treatments but decreased in the poultry manure treatments. Poultry manure is a high nitrogen chemically unstable product resulting in the rapid decomposition of nitrogen into the soil after application (Robinson and Sharpley 1995). High levels of nitrogen in forms such as ammonia, particularly with increased irrigation, amplifies $V$. dahliae proliferation, perhaps explaining the increased populations of $V$. dahliae in poultry manure treatments (Conn and Lazarovits 1999; Sewell and Wilson 1967; Wheeler et al. 2012). Relative increases in $V$. dahliae abundance within the layer ash treatments between sampling dates may be attributed to the slower release of nitrogenous compounds associated with composts (Azim et al. 2018). This trend, however, was not observed in the Dairy Dootreated plots, which showed a decrease in $V$. dahliae abundance between sampling dates. This could be due to a lack of VFAs and total Kjeldahl nitrogen within the compost compared with the layer ash blend and poultry manure.

Despite the high abundance of $V$. dahliae observed, poultry manure-treated plots resulted in significantly higher yields than the control and numerically higher yields than the grower standard, Vydate. Using data collected in this and other Michigan potato field trials, Dyrdahl-Young et al. (2020) found a 61 and 56\% mean increase in net revenues in plots treated with poultry manure and layer ash blend, respectively, when compared with the control, while Vydate only averaged net returns $52 \%$ higher than the control.

Overall, this study indicates that poultry manure and the layer ash blend have the highest potential for nematode control with VFAs potentially playing a significant role in this reduction. Poultry manure, in particular, demonstrated significant ability to reduce nematode populations and increase yield, but rate of application was a key factor. It is likely that the high rate of poultry manure resulted in slight phytotoxicity, thereby resulting in marginally lower yields than the poultry low treatment despite the reduced nematode populations. Perhaps an intermediate application rate would provide optimal control of nematodes and improve yield. Additionally, a high rate of poultry manure may increase $V$. dahliae abundance; however, more studies on the direct influence of poultry manure on $V$. dahliae are needed. Should a grower decide to implement poultry manure in their field, preventative measures should be taken to mitigate the risk of $V$. dahliae. Despite this, the potential for nematode control is critical since nematodes are a driving factor for PED development. Ultimately, PED control will likely stem from multiple control tactics, but our study provides an additional insight into PED control.

\section{ACKNOWLEDGMENTS}

We thank Kristin Poley, Brian Levene, Elisabeth Darling, Lauren Rodriguez, John Calogero, Trina Zavislan, and Chris Long for technical assistance as well as Zsofia Szendrei, Matthew Grieshop, and Jamie Willbur for discussion and editing during the early drafts of this manuscript.

\section{LITERATURE CITED}

Azim, K., Soudi, B., Boukhari, S., Perissol, C., Roussos, S., and Thami Alami, I. 2018. Composting parameters and compost quality: A literature review. Org. Agric. 8:141-158.

Bird, G. W. 1971. Influence of incubation solution on the rate of recovery of Pratylenchus brachyurus from cotton roots. J. Nematol. 3:378-385.

Brinton, W. F. 1998. Volatile organic acids in compost: Production and odorant aspects. Compost Sci. Util. 6:75-82.

Browning, M., Dawson, C., Alm, S. R., Gorrës, J. H., and Amador, J. A. 2004. Differential effects of butyric acid on nematodes from four trophic groups. Appl. Soil Ecol. 27:47-54.

Butler, D. M., Kokalis-Burelle, N., Muramoto, J., Shennan, C., McCollum, T. G., and Rosskopf, E. N. 2012. Impact of anaerobic soil disinfestation combined with soil solarization on plant-parasitic nematodes and introduced inoculum of soilborne plant pathogens in raised-bed vegetable production. Crop Prot. 39:33-40.

Clark, M. S., Horwath, W. R., Shennan, C., and Scow, K. M. 1998. Changes in soil chemical properties resulting from organic and low-input farming practices. Agron. J. 90:662-671.

Collins, H. P., Alva, A., Boydston, R. A., Cochran, R. L., Hamm, P. B., McGuire, A., and Riga, E. 2006. Soil microbial, fungal, and nematode responses to soil fumigation and cover crops under potato production. Biol. Fertil. Soils 42:247-257.

Conn, K. L., and Lazarovits, G. 1999. Impact of animal manures on Verticillium wilt, potato scab, and soil microbial populations. Can. J. Plant Pathol. 21:81-92. 
Conn, K. L., Tenuta, M., and Lazarovits, G. 2005. Liquid swine manure can kill Verticillium dahliae microsclerotia in soil by volatile fatty acid, nitrous acid, and ammonia toxicity. Phytopathology 95:28-35.

Davies, K. G., and Curtis, R. H. C. 2011. Cuticle surface coat of plant-parasitic nematodes. Annu. Rev. Phytopathol. 49:135-156.

De Ruijter, F. J. D., and Haverkort, A. J. 1999. Effects of potato-cyst nematodes (Globodera pallida) and soil $\mathrm{pH}$ on root growth, nutrient uptake and crop growth of potato. Eur. J. Plant Pathol. 105:61-76.

Demeyer, A., Nkana, J. C. V., and Verloo, M. G. 2001. Characteristics of wood ash and influence on soil properties and nutrient uptake: An overview. Bioresour. Technol. 77:287-295.

Dickson, D. W., and Hewlett, T. E. 1988. Efficacy of fumigant and nonfumigant nematicides for control of Meloidogyne arenaria on peanut. J. Nematol. 20:95-101.

Dyrdahl-Young, R., Cole, E., Tornel, M. Q., Weldon, R., and DiGennaro, P. 2020. Economic assessment of nematode biological control agents in a potato production model. Nematology 1:1-9.

EPA. 2005. Overview of the use and usage of soil fumigants. U.S. Environmental Protection Agency. https://archive.epa.gov/pesticides/reregistration/ web/pdf/soil_fumigant_use.pdf

Everts, K. L., Sardanelli, S., Kratochvil, R. J., Armentrout, D. K., and Gallagher, L. E. 2006. Root-knot and root-lesion nematode suppression by cover crops, poultry litter, and poultry litter compost. Plant Dis. 90:487-492.

FAO. 2001. Global report on validated alternatives to the use of methyl bromide for soil fumigation. Food and Agriculture Organization. http:// www.fao.org/3/y1809e00.htm

Forge, T., Kenney, E., Hashimoto, N., Neilsen, D., and Zebarth, B. 2016. Compost and poultry manure as preplant soil amendments for red raspberry: Comparative effects on root lesion nematodes, soil quality and risk of nitrate leaching. Agric. Ecosyst. Environ. 223:48-58.

Ghorbani, R., Koocheki, A., Jahan, M., and Asadi, G. A. 2008. Impact of organic amendments and compost extracts on tomato production and storability in agroecological systems. Agron. Sustain. Dev. 28:307-311.

Giannakou, I. O., and Karpouzas, D. G. 2003. Evaluation of chemical and integrated strategies as alternatives to methyl bromide for the control of root-knot nematodes in Greece. Pest Manag. Sci. 59:883-892.

Goud, J.-K. C., Termorshuizen, A. J., and Gams, W. 2003. Morphology of Verticillium dahliae and V. tricorpus on semi-selective media used for the detection of $V$. dahliae in soil. Mycol. Res. 107:822-830.

Ibekwe, A. M. 2004. Effects of fumigants on non-target organisms in soils. Adv. Agron. 83:1-35.

Janssen, T., Karssen, G., Orlando, V., Subbotin, S. A., and Bert, W. 2017. Molecular characterization and species delimiting of plant-parasitic nematodes of the genus Pratylenchus from the penetrans group (Nematoda: Pratylenchidae). Mol. Phylogenet. Evol. 117:30-48.

Jenkins, W. R. 1964. A rapid centrifugal-flotation technique for separating nematodes from soil. Plant Dis. Rep. 48:692.

Kimpinski, J., Arsenault, W. J., Gallant, C. E., and Sanderson, J. B. 2000. The effect of marigolds (Tagetes spp.) and other cover crops on Pratylenchus penetrans and on following potato crops. J. Nematol. 32:531-536.

Korthals, G. W., Thoden, T. C., van den Berg, W., and Visser, J. H. M. 2014. Longterm effects of eight soil health treatments to control plant-parasitic nematodes and Verticillium dahliae in agro-ecosystems. Appl. Soil Ecol. 76:112-123.

Larkin, R. P., Griffin, T. S., and Honeycutt, C. W. 2010. Rotation and cover crop effects on soilborne potato diseases, tuber yield, and soil microbial communities. Plant Dis. 94:1491-1502.

Lenth, R., Singmann, H., Love, J., Buerkner, P., and Herve, M. 2019. Estimated marginal means, aka least-squares means. https://github.com/rvlenth/ emmeans

Macalady, J. L., Fuller, M. E., and Scow, K. M. 1998. Effects of metam sodium fumigation on soil microbial activity and community structure. J. Environ. Qual. 27:54-63.

Mace, M. E., Bell, A. A., and Beckman, C. H. (eds.) 1981. Fungal Wilt Diseases of Plants. Academic Press, Cambridge, MA.

Mahran, A., Tenuta, M., Hanson, M. L., and Daayf, F. 2008. Mortality of Pratylenchus penetrans by volatile fatty acids from liquid hog manure. J. Nematol. 40:119-126.

McBride, R. G., Mikkelsen, R. L., and Barker, K. R. 2000. The role of low molecular weight organic acids from decomposing rye in inhibiting rootknot nematode populations in soil. Appl. Soil Ecol. 15:243-251.

Mkhabela, M. S., and Warman, P. R. 2005. The influence of municipal solid waste compost on yield, soil phosphorus availability and uptake by two vegetable crops grown in a Pugwash sandy loam soil in Nova Scotia. Agric. Ecosyst. Environ. 106:57-67.

Molina, O. I., Tenuta, M., Hadrami, A. E., Buckley, K., Cavers, C., and Daayf, F. 2014. Potato early dying and yield responses to compost, green manures, seed meal and chemical treatments. Am. J. Potato Res. 91:414-428.

Nadakavukaren, M. J., and Homer, C. E. 1959. An alcohol agar medium selective for determining Verticillium microsclerotia in soil. Phytopathology 49:527-528.

Nagy, P., Bakonyi, G., Bongers, T., Kádár, I., Fábián, M., and Kiss, I. 2004. Effects of microelements on soil nematode assemblages seven years after contaminating an agricultural field. Sci. Total Environ. 320:131-143.

NASS. 2018. State Agriculture Overview-Michigan. https://www.nass.usda.gov/ Quick_Stats/Ag_Overview/stateOverview.php?state=MICHIGAN

Nicot, P. C., and Rouse, D. I. 1987a. Relationship between soil inoculum density of Verticillium dahliae and systemic colonization of potato stems in commercial fields over time. Phytopathology 77:1346-1355.

Nicot, P. C., and Rouse, D. I. 1987b. Precision and bias of three quantitative soil assays for Verticillium dahliae. Phytopathology 77:875-881.

O’Malley, M., Marylou Verder-Carlos, M., and Louise Mehler, P. 2005. Illnesses related to shank application of metam-sodium, Arvin, California, July 2002. J. Agromed. 10:27-42.

Oka, Y. 2010. Mechanisms of nematode suppression by organic soil amendments-A review. Appl. Soil Ecol. 44:101-115.

Oka, Y. 2014. Nematicidal activity of fluensulfone against some migratory nematodes under laboratory conditions. Pest Manag. Sci. 70:1850-1858.

Plachá, D., Raclavská, H., Kučerová, M., and Kuchařová, J. 2013. Volatile fatty acid evolution in biomass mixture composts prepared in open and closed bioreactors. Waste Manag. 33:1104-1112.

Porter, I., Pizano, M., Besri, M., Mattner, S. W., and Fraser, P. 2010. Progress in the global phase out of methyl bromide and the relative effectiveness of soil disinfestation strategies. Acta Hortic. 883:59-66.

Powelson, R. L., and Carter, G. E. 1973. Efficacy of soil fumigants for control of Verticillium wilt of potatoes. Am. Potato J. 50:162-167.

R Core Team. 2018. R: A language and environment for statistical computing. R Foundation for Statistical Computing, Vienna, Austria. https://www.Rproject.org/

Robinson, J. S., and Sharpley, A. N. 1995. Release of nitrogen and phosphorus from poultry litter. J. Environ. Qual. 24:62-67.

Rowe, R. C., and Powelson, M. L. 2002. Potato early dying: Management challenges in a changing production environment. Plant Dis. 86:1184-1193.

Santos, B. M., Gilreath, J. P., Motis, T. N., Noling, J. W., Jones, J. P., and Norton, J. A. 2006. Comparing methyl bromide alternatives for soilborne disease, nematode and weed management in fresh market tomato. Crop Prot. 25:690-695.

Schneider, S. M., Ajwa, H. A., Trout, T. J., and Gao, S. 2008. Nematode control from shank- and drip-applied fumigant alternatives to methyl bromide. HortScience 43:1826-1832

Sewell, G. W. F., and Wilson, J. F. 1967. Verticillium wilt of the hop: Field studies on wilt in a resistant cultivar in relation to nitrogen fertilizer applications. Ann. Appl. Biol. 59:265-273.

South, D., and Carey, B. 2000. Economics of soil fumigation. South. J. Appl. For. 98:S4.

South, D. B., and Gjerstad, D. H. 1980. Nursery weed control with herbicides or fumigation-An economic evaluation. South. J. Appl. For. 4:40-45.

Stoffella, P. J., and Kahn, B. A. 2001. Compost Utilization in Horticultural Cropping Systems. CRC Press, Boca Raton, FL.

Tenuta, M., Conn, K. L., and Lazarovits, G. 2002. Volatile fatty acids in liquid swine manure can kill microsclerotia of Verticillium dahliae. Phytopathology 92:548-552

U.S. Department of Agriculture-Natural Resources Conservation Service. 2019. Web Soil Survey. https://websoilsurvey.sc.egov.usda.gov/

Vestergård, M., Bang-Andreasen, T., Buss, S. M., Cruz-Paredes, C., BentzonTilia, S., Ekelund, F., Kjoller, R., Mortensen, L. H., and Ronn, R. 2018. The relative importance of the bacterial pathway and soil inorganic nitrogen increase across an extreme wood-ash application gradient. Glob. Change Biol. Bioenergy 10:320-334.

Wheeler, T. A., Bordovsky, J. P., Keeling, J. W., and Mullinix, B. G. 2012. Effects of crop rotation, cultivar, and irrigation and nitrogen rate on Verticillium wilt in cotton. Plant Dis. 96:985-989.

Woolliams, G. E. 1966. Host range and symptomatology of Verticillium dahliae in economic, weed, and native plants in interior British Columbia. Can. J. Plant Sci. 46:661-669. 